\title{
STUDI PERKEMBANGAN IMPLEMENTASI PERATURAN TATA RUANG KAWASAN SENTRA PRIMER BARAT PURI INDAH SEBAGAI PUSAT KOTA BARU
}

\author{
Andi Saputra $^{1)}$, Suryono Herlambang ${ }^{2)}$ \\ 1)Program Studi S1 PWK, Fakultas Teknik, Universitas Tarumanagara, andi.345150008@stu.untar.ac.id \\ 2) Program Studi S1 PWK, Fakultas Teknik, Universitas Tarumanagara, suryonoh@ft.untar.ac.id
}

\begin{abstract}
Abstrak
Aktivitas pertumbuhan terkonsentrasi di dalam kawasan segitiga emas yakni koridor ThamrinSudirman-Kuningan, namun dalam beberapa tahun terakhir ini, pengembangan justru sedang bertumbuh di kawasan barat dan timur Jakarta atau yang lebih dikenal sebagai Kawasan Sentra Primer Barat dan Kawasan Sentra Primer Timur. Rencana pengembangan Kawasan Sentra Primer Barat pada awalnya dapat dilihat pada Peraturan Daerah DKI Jakarta No. 6 Tahun 1999, dimana pengembangan yang ada bertujuan agar tercapainya keseimbangan ekosistem dan pemerataan ekonomi yang ada di Jakarta serta menjadikan Kawasan Sentra Primer Barat sebagai pusat kegiatan primer yang ada di Kota Jakarta Barat. Terdapat beberapa aspek yang menjadi fokus perencanaan yaitu jaringan jalan, penggunaan lahan, intensitas bangunan, sampai dengan perencanaan transportasi umum. Kawasan Sentra Primer Barat berada pada Kawasan Puri Indah yang mencakup area seluas 135 ha. Melalui penelitian ini dilakukan studi mengenai perkembangan implementasi peraturan tata ruang di Kawasan Sentra Primer Barat Puri Indah sebagai pusat kota baru untuk mengetahui apakah kondisi eksisting Kawasan Sentra Primer Barat sudah memenuhi dan sesuai dengan perencanaannya sebagai pusat kegiatan primer. Analisis yang dilakukan adalah analisis kebijakan, analisis kedudukan, analisis spasial, analisis perkembangan properti, dan analisis sektor informal. Alat yang digunakan dalam penelitian ini adlaah analisis timeline, mapping ArcGIS, dan deskriptif kualitatif. Hasil dari penelitian ini adalah kondisi eksisting Kawasan Sentra Primer Barat belum memenuhi dan sesuai dengan perencanaannya sebagai pusat kegiatan primer yang ada di Kota Jakarta Barat yang dilihat berdasarkan beberapa aspek yaitu jumlah penduduk, perkembangan kawasan, infrastruktur jalan, dan transportasi umum.
\end{abstract}

Kata Kunci: Kawasan Sentra Primer Barat; Perkembangan Kota; Pusat Kegiatan Primer

\begin{abstract}
Growth activities are concentrated in the golden triangle, but in recent years development has actually been growing in the western and eastern regions of Jakarta, known as the West Primary Center and East Primary Center. The plan to develop the West Primary Center was initially seen in the DKI Jakarta Regional Regulation, where the existing development aims to achieve the balance of ecosystems and economic equality in Jakarta and make the West Primary Center as the center of primary activities in West Jakarta City. There are several aspects that are the focus of planning, road network, land use, building intensity, and public transportation. The West Primary Center is located in the Puri Indah area which covers an area of $135 \mathrm{ha}$. Through this research a study was conducted on the development of the implementation of spatial regulations in West Primary Center Puri Indah as a new city center to find out whether the existing conditions of the West Primary Center have fulfilled and are in accordance with their planning as the primary activity center. The analysis carried out were policy, position, spatial, property development, and the informal sector. The tools used in this research are timeline analysis, ArcGIS mapping, and qualitative descriptive. The result of this research is the existing condition of the West Primary Center hasn't fulfilled with its planning as a center for primary activities in West Jakara City which is seen based on several aspects.
\end{abstract}

Keywords: City Development; Primary Center Area; Primary Activity Center 


\section{PENDAHULUAN}

Seiring semakin maju nya kota-kota yang ada di Indonesia menjadikan kota-kota tersebut lebih mandiri. Sebagai contoh adalah Kota Jakarta yang merupakan ibukota negara Indonesia yang juga pasti tentunya merupakan pusat pemerintahan, pusat politik, dan pusat administrasi negara. Seiring semakin majunya Kota Jakarta, fungsi yang ada juga terus bertambah menjadi pusat perdagangan dan jasa, pusat industri, pusat pendidikan, budaya, sosial, rekreasi, maupun pengembangan wisata. Namun dari sekian banyak pertambahan fungsi yang ada di Jakarta, dirasa fungsi sebagai pusat perdagangan dan jasa merupakan fungsi yang paling menonjol dari antara fungsi yang lainnya.

Dengan luasan lahan yang terbatas namun multifungsi, Kota Jakarta memerlukan strategi perencanaan dan pengembangan yang tepat untuk memikul beban multifungsi ini. Namun perencanaan dan pengembangan yang dilakukan juga tetap harus memperhatikan keseimbangan dan keberlanjutan dari lingkungan sekitar. Awalnya kawasan dengan fungsi sebagai pusat perdagangan dan jasa lebih menonjol di daerah Jakarta Selatan seperti kawasan Sudirman Central Business District (SCBD), namun seiring dengan semakin banyaknya pengembangan di daerah Jakarta Selatan menjadikan lahan kosong yang ada lama kelamaan mulai habis. Jika selama satu hingga dua dekade silam pertumbuhan terkonsentrasi di wilayah yang termasuk dalam kawasan segitiga emas (golden triangle) yakni koridor Thamrin-SudirmanKuningan, maka dalam beberapa tahun terakhir ini, pengembangan justru sedang bertumbuh di kawasan barat dan timur Jakarta atau yang lebih dikenal sebagai Kawasan Sentra Primer Barat dan Kawasan Sentra Primer Timur.

Awal mula perencanaan Kawasan Puri Indah sebagai Sentra Primer Barat dapat dilihat pada dokumen Urban Design Guidelines (UDGL) tahun 2006 mengenai Kawasan Sentra Primer Barat. Seiring dengan perencanaan tersebut ketentuan mengenai batas maksimal intensitas bangunan yang boleh dibangun di kawasan tersebut juga meningkat. Sebagai contoh hal ini dapat dilihat pada dokumen Lembar Rencana Kota (LRK), Urban Design Guide Lines (UDGL) tahun 2006 dan Rencana Detail Tata Ruang (RDTR) tahun 2014, dimana terdapat perbedaan untuk intensitas bangunan yang direncanakan terutama berkaitan dengan Koefisien Lantai Bangunan (KLB). Selain berkaitan dengan perkembangan intensitas bangunan, perkembangan lain yang juga perlu diperhatikan dari Kawasan Puri Indah berkaitan dengan kebijakan terkait Kawasan Sentra Primer Barat, kedudukan Puri Indah di Kota Jakarta, penggunaan lahan, jaringan jalan, demografi, jaringan transportasi umum, infrastruktur, dan perkembangan properti di Kawasan Sentra Primer Barat. Dari perkembangan tersebut maka dapat dilihat apakah kondisi eksisting Kawasan Puri Indah tahun 2019 sudah memenuhi dan sesuai dengan perencanaan sebagai Kawasan Sentra Primer Barat. Penelitian ini bertujuan untuk mengetahui sejarah perkembangan dan kebijakan pemerintah terkait Kawasan Puri Indah yang direncanakan sebagai Kawasan Sentra Primer Barat, mengetahui kedudukan Kawasan Sentra Primer Barat di Kota Jakarta, dan mengevaluasi kesesuaian antara kondisi eksisting Kawasan Sentra Primer Barat dengan perencanaannya sebagai Kawasan Sentra Primer.

\section{KAJIAN LITERATUR}

\section{Kawasan Sentra Primer}

Menurut Peraturan Daerah DKI Jakarta No. 6 Tahun 1999 yang dimaksud dengan kawasan sentra primer adalah kawasan dalam pusat kegiatan yang menurut hierarkinya termasuk dalam sistem pusat utama. Sementara yang dimaksudkan dengan kawasan sistem pusat kegiatan adalah kawasan yang diarahkan bagi pemusatan berbagai kegiatan campuran maupun yang spesifik, memiliki fungsi strategis dalam menarik berbagai kegiatan pemerintah, sosial, ekonomi, dan budaya serta kegiatan pelayanan kota menurut hierarki terdiri dari sistem pusat kegiatan utama yang berskala kota, regional, nasional, dan internasional serta sistem pusat penunjang yang berskala lokal. 


\section{Central Business District}

Menurut Murphy dan Vance (1954), Central Business District (CBD) digambarkan sebagai jantung kota yang terletak pada bagian tengah kota, yang di dalamnya terdapat kegiatan pusat tertentu seperti bank, kantor, hotel, dan teater. Menurut Sun (2011), Central Business District (CBD) adalah pusat yang mengintegrasikan banyak lembaga keuangan, bisnis, budaya, pelayanan, serta fasilitas pendukung seperti gedung perkantoran, hotel, dan apartemen yang saling terinteraksi dengan sempurna antara infrastruktur yang ada. Selain itu CBD juga merupakan lingkungan tempat pengembangan ekonomi yang menguntungkan dan tempat yang nyaman untuk kegiatan komersial.

\section{Karakteristik Central Business District}

Menurut Sun (2011), berikut adalah karakteristik dari Central Business District (CBD) :

Tabel 1. Karakteristik Central Business District

\begin{tabular}{c|l}
\hline \multicolumn{1}{c}{ Karakteristik } \\
\hline Fungsi Kegiatan & $\begin{array}{l}\text { Kegiatan bisnis, perkantoran serta fasilitas rekreasi bersifat intensif dan } \\
\text { memiliki daya tarik yang kuat. Fungsi dan pelayanan yang disediakan oleh } \\
\text { area CBD selalu yang tertinggi dibanding area sekitarnya. Area CBD } \\
\text { memiliki tingkat sentralisasi pelayanan tertinggi dan memberikan } \\
\text { pelayananan yang luas untuk kebutuhan ekonomi, manajemen, rekreasi, } \\
\text { budaya, dan administrasi }\end{array}$ \\
\hline $\begin{array}{c}\text { Penggunaan } \\
\text { Lahan }\end{array}$ & $\begin{array}{l}\text { Lahan di lokasi CBD memiliki nilai, intensitas eksplotasi, dan pemanfaatan } \\
\text { lahan paling tinggi dibandingkan dengan wilayah perkotaan lainnya }\end{array}$ \\
\hline $\begin{array}{c}\text { Intensitas } \\
\text { Bangunan }\end{array}$ & $\begin{array}{l}\text { Rasio luas dan kepadatan bangunan tinggi, bentuk bangunan tumbuh } \\
\text { secara vertikal }\end{array}$ \\
\hline Populasi & $\begin{array}{l}\text { CBD memiliki arus pengunjung dan jumlah penduduk lebih banyak } \\
\text { dibandingkan dengan wilayah perkotaan lainnya }\end{array}$ \\
\hline Kondisi Lalu & $\begin{array}{l}\text { Memiliki lalu lintas yang padat serta memiliki aksesibilitas yang lebih } \\
\text { banyak dan keterhubungan antara lalu lintas internal maupun eksternal }\end{array}$ \\
\hline
\end{tabular}

Sumber : Development and Characteristics of Central Business District Under the Philosophy of Health, 2011

\section{METODE}

Data yang akan dikumpulkan selama proses penelitian adalah sejarah perkembangan Kawasan Sentra Primer Barat, kebijakan pemerintah dan dokumen perencanaan terkait Kawasan Sentra Primer Barat, Lembar Rencana Kota, Urban Design Guidelines (UDGL) tahun 2006, Rencana Detail Tata Ruang (RDTR) tahun 2014, jumlah penduduk, perkembangan properti, dan perkembangan serta rencana terkait pedagang kaki lima di Kawasan Sentra Primer Barat.

Teknik pengumpulan data yang dilakukan dalam penelitian ini terbagi atas metode pengumpulan data primer dan pengumpulan data sekunder. Untuk metode pengumpulan data primer dilakukan dengan observasi/survei lapangan dan wawancara dengan pihak-pihak terkait. Sementara untuk metode pengumpulan data sekunder dilakukan dengan dokumentasi dan studi literatur.

Untuk analisis yang dilakukan dalam penelitian ini adalah analisis kebijakan terkait Kawasan Sentra Primer Barat, analisis kedudukan Puri Indah di Kota Jakarta, analisis spasial yang terbagi 
menjadi analisis pola ruang, intensitas bangunan, jaringan jalan, demografi, tranportasi umum, dan infrastruktur, analisis perkembangan properti di Kawasan Sentra Primer Barat, dan yang terakhir adalah analisis sektor informal di Kawasan Sentra Primer Barat. Secara keseluruhan alat analisis yang digunakan adalah metode deskriptif kualitatif. Menurut Nazir (2005), metode deskriptif kualitatif merupakan suatu metode yang digunakan untuk meneliti suatu objek, suatu sistem pemikiran ataupun suatu peristiwa yang terjadi pada masa sekarang. Tujuan dari penelitian dengan menggunakan metode ini adalah untuk membuat deskripsi, gambaran, atau lukisan secara sistematis, faktual, dan akurat terkait hubungan antar fakta yang diteliti.

\section{DISKUSI DAN HASIL}

\section{Analisis Kebijakan Terkait Kawasan Sentra Primer Barat}

Rencana pengembangan dari masing-masing kebijakan pemerintah saling berkelanjutan antara peraturan yang paling awal yaitu Perda DKI Jakarta No. 6 Tahun 1999 sampai dengan Perda DKI Jakarta No. 1 Tahun 2014. Aspek-aspek yang direncanakan dari perencanaan yang paling awal terus dilanjutkan sampai dengan perencanaan yang paling terakhir yaitu pada Perda No. 1 Tahun 2014. Namun berdasarkan perda tahun 2014 tersebut perencanaan di Kawasan Sentra Primer Barat tidak dijabarkan secara detail, melainkan hanya menjelaskan bahwa Kawasan Sentra Primer Barat dikembangkan untuk kegiatan perdagangan dan jasa seperti perkantoran dan campuran berintensitas tinggi untuk skala pelayanan nasional dan internasional serta pusat pelayanan kota administrasi. Sementara pada perencanaan lainnya dijabarkan secara detail perencanaan pengembangan Kawasan Sentra Primer Barat sampai dengan perencanaan yang melibatkan lingkungan seperti pembangunan taman kota, penanaman pohon pelindung, dan pembangunan serta peningkatan kapasitas saluran untuk mengatasi genangan air. Lalu untuk pejalan kaki akan dibangun dan ditingkatkan fasilitas pejalan kaki yang mendukung pelayanan angkutan umum dan terminal/stasiun terpadu untuk menunjang pergerakan antar moda angkutan umum. Dan yang terakhir perencanaan pembangunan Kawasan Sentra Primer Barat dengan menerapkan konsep superblok. Sementara dapat disimpulkan dari perencanaan-perencanaan terhadap Kawasan Sentra Primer Barat tersebut dapat dilihat bahwa Kawasan Sentra Primer Barat dalam pengembangannya direncanakan sebagai kawasan pusat perdagangan, jasa, dan campuran berintensitas tinggi untuk skala pelayanan nasional dan internasional serta sebagai pusat pemerintahan kotamadya Jakarta Barat.

\section{Analisis Kedudukan Puri Indah di Kota Jakarta}

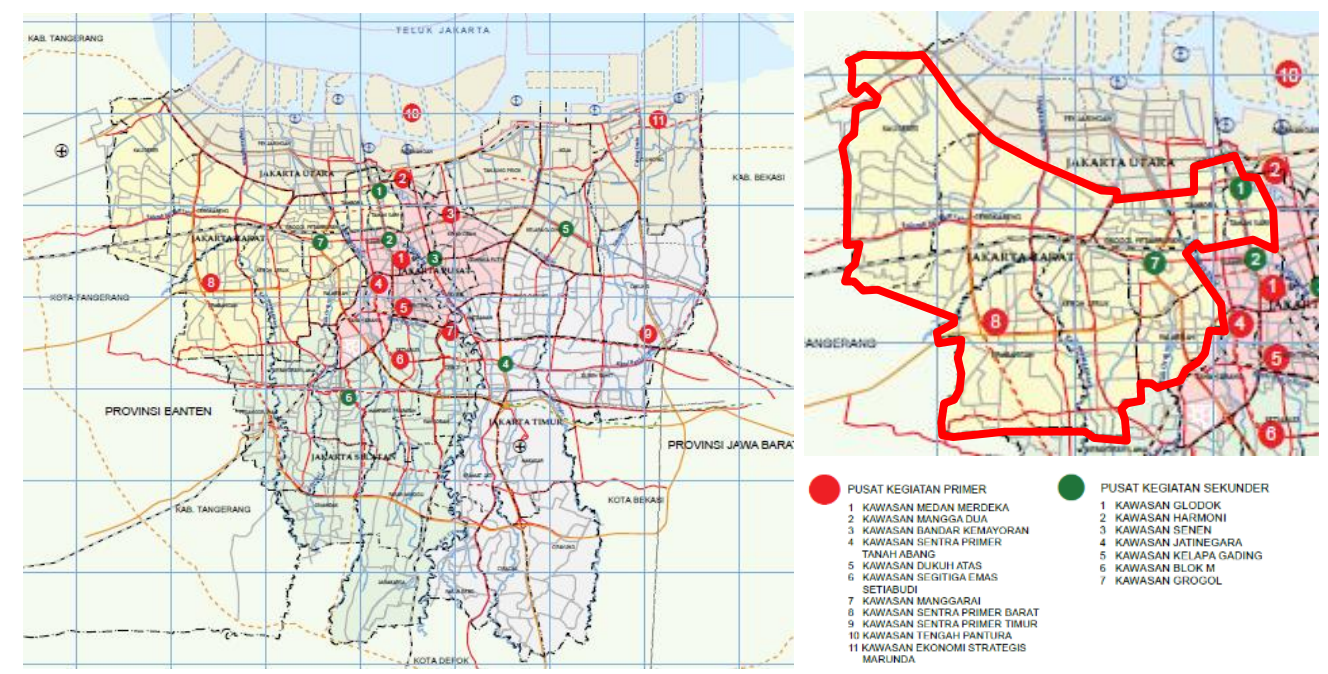

Gambar 1. Peta Rencana Struktur Ruang DKI Jakarta Sumber: Dinas Tata Ruang, 2011 
Berdasarkan Peta Rencana Struktur Ruang DKI Jakarta diatas dapat dilihat bahwa terdapat beberapa pusat kegiatan yang ada di Kota Jakarta, yang dibagi menjadi 2 yaitu pusat kegiatan primer dan pusat kegiatan sekunder. Untuk di Jakarta Barat sendiri terdapat 1 pusat kegiatan primer yaitu Kawasan Sentra Primer Barat dan 2 pusat kegiatan sekunder yaitu Kawasan Grogol dan Kawasan Glodok. Jika dilihat berdasarkan kondisi eksistingnya tahun 2019, Kawasan Grogol yang merupakan pusat kegiatan sekunder justru memiliki daya tarik dan arus pengunjung yang lebih besar dibandingkan dengan Kawasan Sentra Primer Barat. Hal ini disebabkan karena Kawasan Grogol lebih mudah diakses menggunakan transportasi umum dibandingkan dengan Kawasan Sentra Primer Barat. Sementara untuk Kawasan Glodok yang juga merupakan pusat kegiatan sekunder sudah lebih menurun peminat nya karena kebanyakan toko-toko yang ada di Glodok terutama toko elektronik yang merupakan daya tarik disana banyak yang pindah ke daerah Mangga Dua. Selain itu pada Kawasan Glodok juga tidak terdapat bangunan-bangunan komersial yang menjadi daya tarik pengunjung untuk datang ke pusat kegiatan sekunder tersebut.

\section{Analisis Pola Ruang}

Berikut adalah penggunaan lahan berdasarkan Rencana Detail Tata Ruang (RDTR) tahun 2014 dan eksisting tahun 2019 di Kawasan Sentra Primer Barat :

Tabel 2. Implementasi Penggunaan Lahan Berdasarkan Rencana Detail Tata Ruang Tahun 2014

\begin{tabular}{ccccc}
\hline No. & Penggunaan Lahan & $\begin{array}{c}\text { Rencana Detail Tata } \\
\text { Ruang Tahun 2014 }\end{array}$ & $\begin{array}{c}\text { Eksisting } \\
\text { Tahun 2019 }\end{array}$ & Implementasi \\
\hline 1. & Hunian & $31,22 \%$ & $38 \%$ & $6,78 \%$ \\
\hline 2. & Hunian Vertikal & $9,72 \%$ & $3,88 \%$ & $-5,84 \%$ \\
\hline 3. & Hunian Campuran & $15,21 \%$ & $6,07 \%$ & $-9,14 \%$ \\
\hline 4. & Komersial & $32,81 \%$ & $30,30 \%$ & $-2,52 \%$ \\
\hline 5. & Pelayanan Umum dan Sosial & $3,47 \%$ & $1,70 \%$ & $-1,76 \%$ \\
\hline 6. & Pemerintahan Daerah & $4,99 \%$ & $2,27 \%$ & $-2,72 \%$ \\
\hline 7. & Ruang Terbuka Hijau & $1,76 \%$ & $2,44 \%$ & $0,68 \%$ \\
\hline 8. & Ruang Terbuka Biru & $0,81 \%$ & $0,59 \%$ & $-0,22 \%$ \\
\hline 9. & Lahan Kosong & $0 \%$ & $14,74 \%$ & $14,74 \%$ \\
\hline
\end{tabular}

Sumber : Dinas Tata Ruang, Survei Tahun 2019, dan Olahan Penulis

Implementasi dari rencana penggunaan lahan RDTR tahun 2014 pada kondisi eksisting penggunaan lahan tahun 2019 belum seluruhnya terimplementasi. Penggunaan lahan sebagai kawasan hunian pada eksisting tahun 2019 sebesar 38\% sementara pada perencanaannya hanya $31,22 \%$ sehingga menyebabkan luasan penggunaan lahan sebagai kawasan hunian yang ada di Kawasan Sentra Primer Barat lebih luas 6,78\% dari luas yang direncanakan. Sementara untuk penggunaan lahan sebagai kawasan hunian campuran pada implementasinya luasannya masih kurang sebesar $9,36 \%$ dari yang direncanakan. Selain penggunaan lahan sebagai kawasan hunian campuran yang implementasinya masih kurang dari yang direncanakan, penggunaan lahan sebagai kawasan hunian vertikal, komersial, pelayanan umum dan sosial, dan pemerintahan daerah juga masih kurang implementasinya. Hal ini disebabkan karena pada penggunaan lahan eksisting tahun 2019 masih terdapat lahan kosong di Kawasan Sentra Primer Barat sebesar 14,74\% atau sekitar 19,9 Ha. Terkait penggunaan lahan sebagai kawasan Ruang Terbuka Hijau (RTH), pada kondisi eksisting tahun 2019 RTH yang ada di Kawasan Sentra Primer Barat sebesar $2,44 \%$ sementara pada perencanaannya hanya sebesar $1,76 \%$. Tentunya luasan RTH yang lebih besar dibandingkan dengan perencanaannya sangat baik karena itu berarti semakin banyak ruang terbuka hijau yang tersedia di Kawasan Sentra Primer Barat. Namun meskipun demikian 
luasan RTH yang ada sekarang masih tidak memenuhi jika dilihat berdasarkan UU No. 26 Tahun 2007 terkait Penataan Ruang, dimana pada UU tersebut dijelaskan bahwa luasan minimal RTH adalah $30 \%$ dari luas wilayah. Oleh sebab itu dapat disimpulkan bahwa pembangunan di Kawasan Sentra Primer Barat khususnya gedung-gedung tinggi tidak diimbangi dengan penyediaan ruang terbuka hijau.

\section{Analisis Intensitas Bangunan}

Pada analisis intensitas bangunan dilakukan perbandingan antara rencana yang terdapat pada Lembar Rencana Kota (LRK), Urban Design Guidelines (UDGL) tahun 2006, Rencana Detail Tata Ruang (RDTR) tahun 2014 dengan implementasinya pada kondisi eksisting tahun 2019. Dimana intensitas bangunan yang dilihat adalah Koefisien Lantai Bangunan (KLB), Koefisien Dasar Bangunan (KDB), dan Ketinggian Bangunan (KB). Untuk KLB, sebagian besar KLB eksisting tahun 2019 sudah sesuai dengan perencanaannya dengan tidak melebihi batas maksimum yang sudah ditentukan, namun masih terdapat beberapa bangunan yang KLB nya melebihi batas maksimum terutama pada bangunan komersial dan hunian vertikal. Realisasi KLB yang tidak sesuai dengan perencanaan menyebabkan bangunan-bangunan yang tidak sesuai tersebut memiliki luasan melebihi batas maksimal yang sudah direncanakan. Sedangkan untuk KDB, kawasan hunian di Kawasan Sentra Primer Barat rata-rata memiliki KDB yang melebihi batas yang telah ditentukan, khususnya hunian kelas menengah bawah. Realisasi KDB yang tidak sesuai dengan perencanaan menyebabkan kawasan hunian tersebut menjadi padat dikarenakan keseluruhan lahan dijadikan bangunan tanpa menyediakan ruang terbuka. Dan yang terakhir untuk KB, sebagian besar KB eksisting tahun 2019 sudah sesuai dengan perencanaannya dengan tidak melebihi batas maksimum yang sudah ditentukan, namun masih dapat ditemukan beberapa bangunan yang ketinggian bangunannya melebihi batas yang sudah ditentukan.
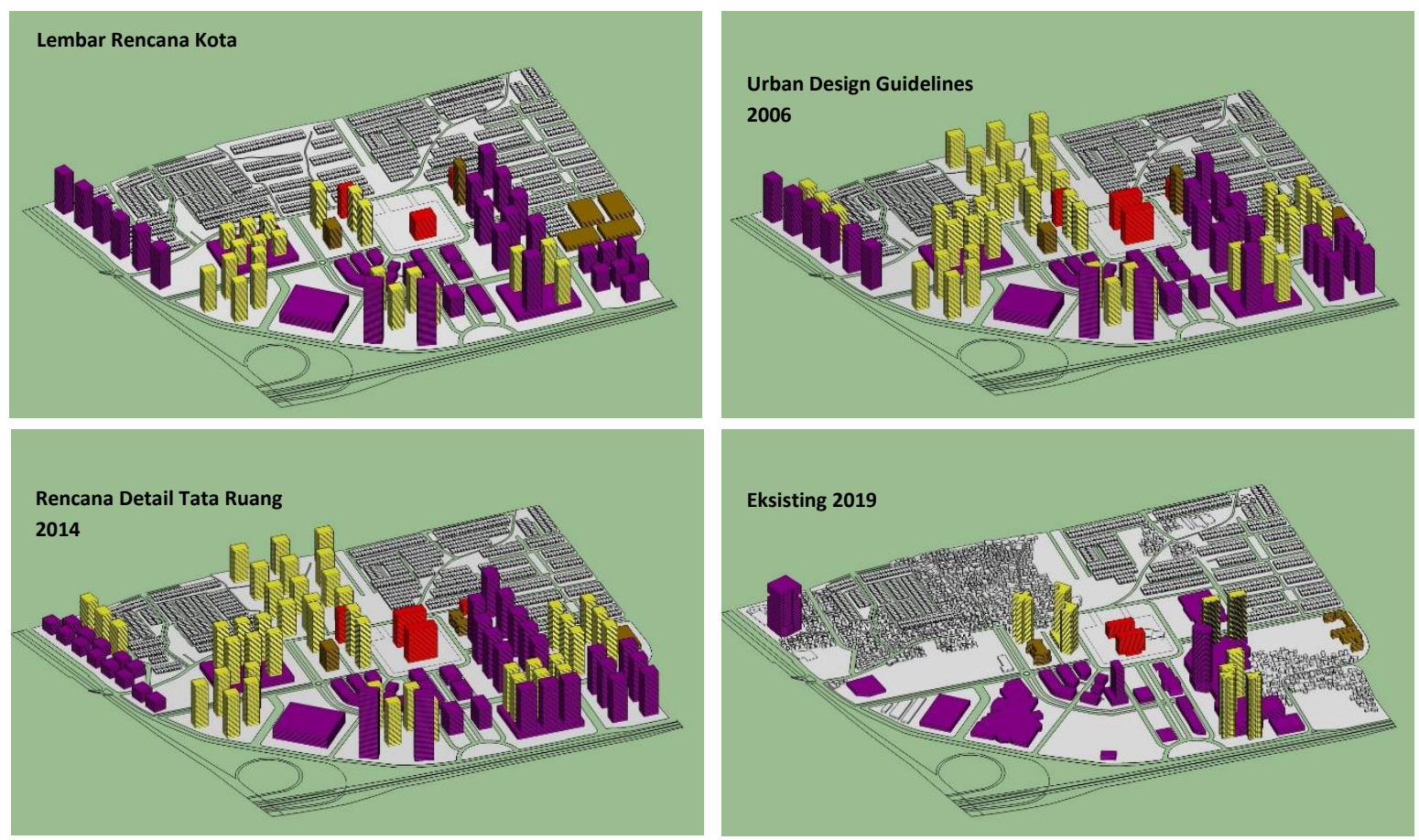

Gambar 2. Kawasan Sentra Primer Barat Berdasarkan Rencana Pengembangan dan Kondisi

Eksisting 2019

Sumber: Penulis, 2019 


\section{Analisis Jaringan Jalan}
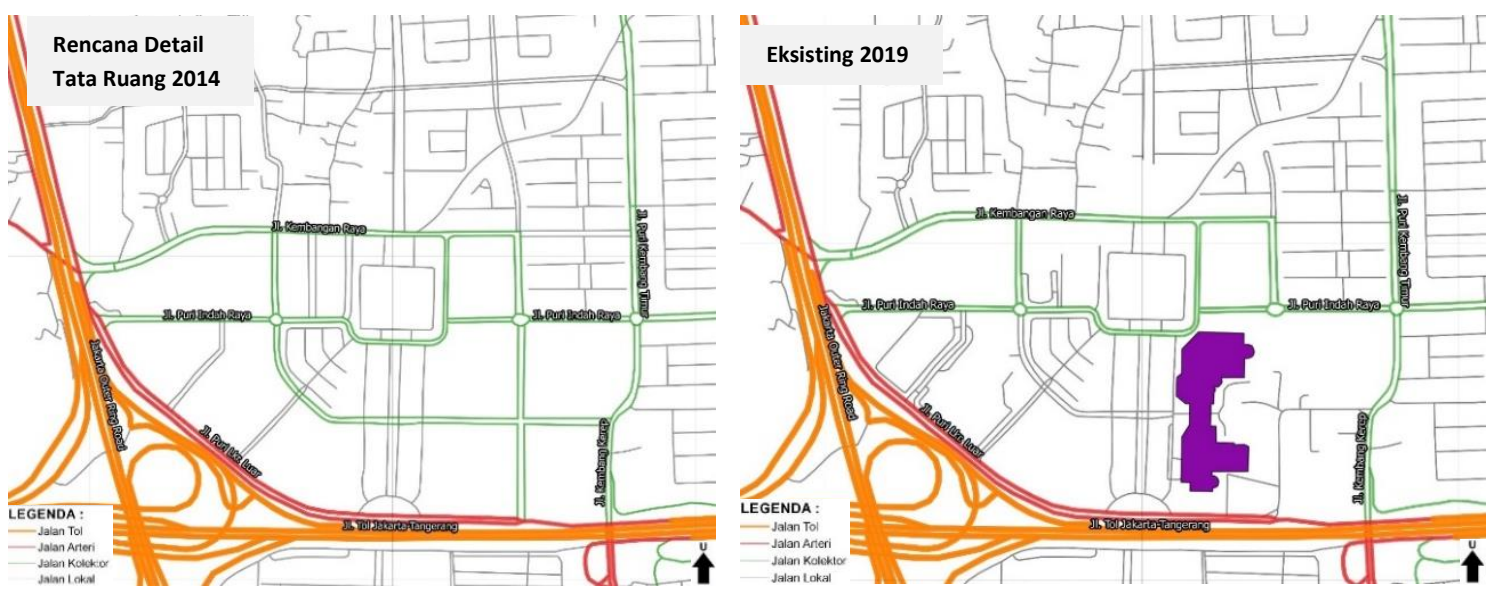

Gambar 2. Jaringan Jalan Kawasan Sentra Primer Barat Menurut RDTR 2014 \& Eksisting 2019 Sumber: Penulis, 2019

Pada kondisi eksisting tahun 2019 masih terdapat beberapa rencana jaringan jalan di Kawasan Sentra Primer Barat yang belum terimplementasi. Sebagai contoh terdapat pada JI. Puri Lkr. Dalam, dimana pada kondisi eksistingnya jalan terputus karena terdapat superblock St. Moritz, padahal menurut perencanaan seharusnya jalan tersebut saling terhubung. Contoh lainnya terdapat pada Jl. Pulau KIp dan Jl. Kembang Murni, pada perencanaan seharusnya kedua jalan tersebut terhubung dengan Jl. Kembangan Raya yang berada di depan Kantor Walikota Jakarta Barat, namun pada implementasinya Jl. Pulau Kelor dan Pulau Klp terputus sehingga tidak terhubung dengan JI. Kembangan Raya.

Belum terimplementasinya rencana jaringan jalan di Kawasan Sentra Primer Barat menyebabkan kondisi lalu lintas eksisting di Kawasan Sentra Primer Barat sering mengalami kemacetan pada titik-titik tertentu terutama pada saat jam pergi dan pulang kerja. Kemacetan tersebut selain disebabkan oleh tidak sesuainya kondisi eksisting dengan perencanaan jaringan jalan, juga disebabkan karena terbatasnya akses di dalam Kawasan Sentra Primer Barat. Keterbatasan akses yang dimaksud disini adalah banyak jalanan yang ditutup dan tidak saling terhubung sehingga menyulitkan pengguna jalan di Kawasan Sentra Primer Barat.

\section{Analisis Transportasi Umum}

Pada kondisi eksisting jaringan transportasi umum yang melewati Kawasan Sentra Primer barat hanya berupa 2 moda tranportasi yaitu bus dan mikrolet. Berdasarkan hasil survei penulis, untuk menggunakan moda transportasi bus transjakarta, diperlukan waktu yang cukup lama untuk menunggu bus transjakarta dengan rute Sentraland Cengkareng-Puri Kembangan datang, begitupun dengan moda transportasi bus dan mikrolet. Selain itu bus transjakarta yang melayani rute Sentraland Cengkareng-Puri Kembangan sebagian besar menggunakan bus feeder, sehingga kapasitas untuk menampung penumpang juga lebih sedikit dibandingkan dengan bus transjakarta biasa. Untuk halte bus transjakarta dan stasiun kereta api rata-rata yang paling dekat berjarak sekitar 5 km dari Kawasan Sentra Primer Barat, sehingga Kawasan Sentra Primer Barat tidak terlayani oleh moda transportasi umum kereta dan bus transjakarta. Tetapi pemerintah telah memiliki perencanaan untuk membangun moda transportasi LRT dengan 7 rute yang salah satu rutenya atau koridor empat melayani Kawasan Puri Indah - Tanah Abang. Perencanaan pembangunan LRT di Kawasan Sentra Primer Barat juga sudah terdapat di dalam rencana RTRW 2012 yaitu pembangunan LRT Koridor Sentra Primer Timur - Sentra Primer Barat. Namun sampai saat ini pembangunan belum selesai dilakukan, sehingga Kawasan Sentra Primer Barat belum terlayani jaringan transportasi umum yang memadai. 


\section{Analisis Infrastruktur}

Kawasan Sentra Primer Barat sudah terlayani oleh jaringan air bersih yang berasal dari PT. PAM Lyonnaise Jaya (PALYJA). Namun area resapan air untuk menyerap air hujan yang berupa Ruang Terbuka Hijau (RTH) pada Kawasan Sentra Primer Barat belum memadai, padahal berdasarkan Undang-Undang Republik Indonesia No. 26 Tahun 2007 terkait Penataan Ruang pada pasal 29 ayat 2 dijelaskan bahwa proporsi ruang terbuka hijau pada wilayah kota paling sedikit 30 (tiga puluh) persen dari luas wilayah kota dan ayat 3 dijelaskan bahwa proporsi ruang terbuka hijau publik pada wilayah kota paling sedikit 20 (dua puluh) persen dari luas wilayah kota. Pada kondisi eksisting tahun 2019, RTH yang ada di Kawasan Sentra Primer Barat hanya 3,3 Ha atau 2\% dari luas keseluruhan Kawasan Sentra Primer Barat. RTH yang ada di Kawasan Sentra Primer Barat berupa jalur hijau dan RTH privat yang berada di dalam kawasan perumahan. Minimnya RTH yang ada di Kawasan Sentra Primer Barat selain tidak sesuai dengan UU No. 26 Tahun 2007 terkait Penataan Ruang yang dimana juga mengakibatkan tidak terdapatnya ruang terbuka sebagai tempat berkumpul serta berinteraksi antar warga yang berada di Kawasan Sentra Primer Barat. Selain itu kurangnya RTH yang tersedia juga tentunya mengakibatkan tidak terdapatnya area resapan air yang cukup untuk menyerap air hujan.

\section{Analisis Demografi}

Jumlah penduduk di Kawasan Sentra Primer Barat pada tahun 2018 adalah 8.813 jiwa, sementara pertumbuhan penduduk di Kawasan Sentra Primer Barat paling tinggi terjadi pada tahun 2010-2011 dengan peningkatan sebesar 30,44\% atau sekitar 2.415 jiwa. Kawasan Sentra Primer Barat memiliki kepadatan penduduk sebesar 65 jiwa/ha dan rata-rata pertumbuhan penduduk $3,96 \%$.

\section{Analisis Properti di Kawasan Sentra Primer Barat}

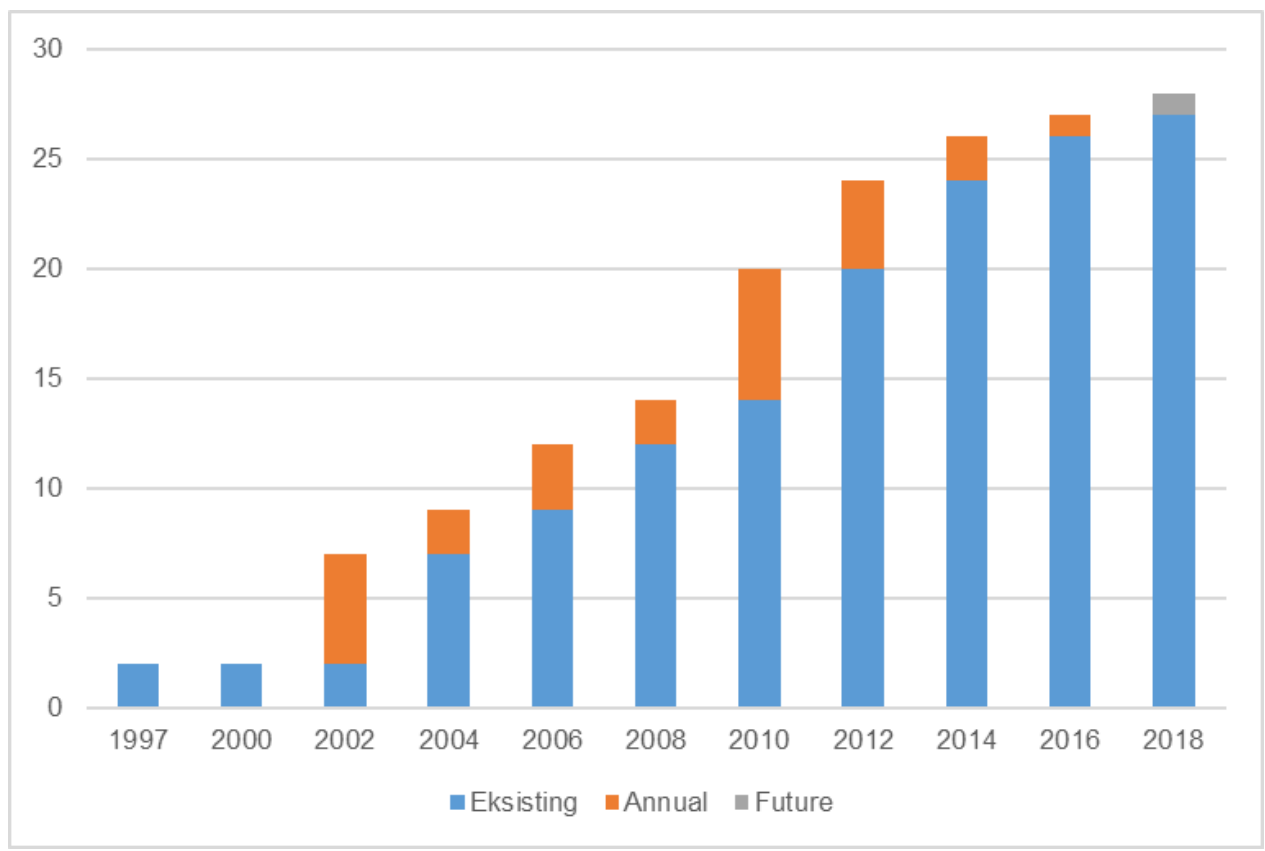

Gambar 3. Perkembangan Properti di Kawasan Sentra Primer Barat Sumber: Penulis, 2019

Properti yang ada di Kawasan Sentra Primer Barat sudah mulai berkembang sejak tahun 1997, dimana properti yang dibangun pertama kali di Kawasan Sentra Primer Barat merupakan properti dengan fungsi sebagai bangunan komersial, yaitu Puri Indah Mall dan Ruko Sentra Niaga Puri. Setelah pembangunan di tahun 1997 tersebut, pembangunan selanjutnya terjadi sekitar 
tahun 2000an yaitu pembangunan Kantor Walikota Jakarta Barat yang merupakan bangunan pemerintahan, Carrefour Puri Indah yang merupakan bangunan komersial, Notre Dame yang merupakan bangunan sekolah, dan perumahan Puri Indah yang merupakan kawasan bangunan hunian.

Dari grafik diatas dapat dilihat bahwa properti di Kawasan Sentra Primer Barat paling banyak mengalami perkembangan pada tahun 2002 dan tahun 2010. Sebagian besar properti yang dibangun di Kawasan Sentra Primer Barat merupakan bangunan dengan fungsi sebagai kawasan komersial seperti gedung perkantoran dan pusat perbelanjaan. Selain gedung perkantoran dan pusat perbelanjaan, bangunan apartemen juga cukup banyak yang berada di Kawasan Sentra Primer Barat seperti Apartemen St. Moritz, Apartemen The Windsor, dan Apartemen Puri Garden. Untuk gedung apartemen selain yang sudah ada di Kawasan Sentra Primer Barat pada kondisi eksisting 2019, sudah terdapat rencana pembangunan yaitu gedung Apartemen Prosperity. Selain rencana pembangunan tersebut, masih memungkinkan untuk dilakukan pembangunan properti lain di Kawasan Sentra Primer Barat jika dilihat dari luasan lahan kosong yang masih tersedia.

\section{Analisis Sektor Informal di Kawasan Sentra Primer Barat}

Lokasi dari sektor informal yaitu Pedagang Kaki Lima (PKL) di Kawasan Sentra Primer Barat tepatnya berada di depan Lippo Mall Puri. Untuk lebih jelasnya terkait lokasi pedagang kaki lima di Kawasan Sentra Primer Barat dapat dilihat pada peta nomor 30. PKL yang ada di Kawasan Sentra Primer Barat sudah mulai berjualan sejak tahun 2006, bahkan saat Lippo Mall Puri belum dibangun dan masih berupa rawa-rawa. Berdasarkan hasil wawancara dengan beberapa PKL yang ada di Kawasan Sentra Primer Barat, pada tahun 2006 jumlah PKL yang berjualan di Kawasan Sentra Primer Barat hanya berjumlah sekitar 15-20 PKL. Lalu perlahan-lahan bertambah hingga jumlah PKL yang berjualan di depan Lippo Mall Puri pada tahun 2019 sekitar 86 PKL. Untuk lebih jelasnya terkait perkembangan PKL di Kawasan Sentra Primer Barat dapat dilihat pada grafik dibawah ini :

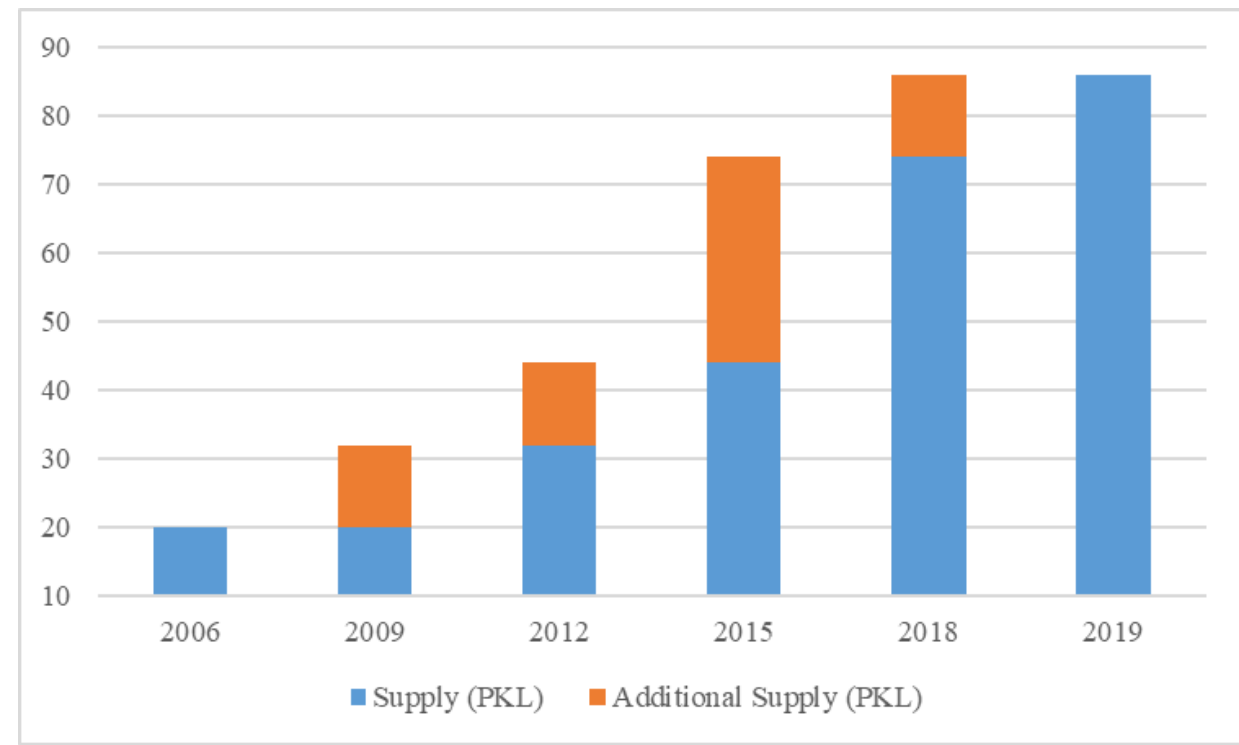

Gambar 4. Perkembangan Pedagang Kaki Lima di Kawasan Sentra Primer Barat Sumber: Penulis, 2019

Berdasarkan grafik diatas dapat dilihat bahwa PKL yang ada di Kawasan Sentra Primer Barat terus bertambah jumlahnya dari tahun ke tahun. Namun untuk pertambahan jumlah PKL yang paling banyak terjadi pada tahun 2012-2015, dimana terdapat pertambahan sebanyak 30 PKL. Berdasarkan hasil wawancara dengan PKL dan pihak Karang Taruna, pertambahan jumlah PKL paling banyak terjadi di tahun tersebut dikarenakan pembangunan superblok St. Moritz yang 
sudah selesai dan mulai beroperasi, sehingga Kawasan Sentra Primer Barat menjadi lebih ramai. Oleh sebab itu dapat disimpulkan bahwa perkembangan sektor informal tersebut dipengaruhi oleh perkembangan sektor formal yang ada di Kawasan Sentra Primer Barat. Jenis barang jualan PKL yang terdapat di Kawasan Sentra Primer Barat beraneka ragam. Namun secara keseluruhan, PKL yang menjual makanan dan minuman merupakan yang paling banyak daripada PKL yang menjual barang-barang lainnya.

Keberadaan sektor informal yang berupa PKL di Kawasan Sentra Primer Barat selain memberikan dampak positif juga tentunya memberikan dampak negatif. Dampak positif dari keberadaan PKL di Kawasan Sentra Primer Barat adalah kawasan menjadi lebih ramai dan hidup dikarenakan terdapat aktivitas jual beli maupun interaksi sosial antara pengunjung yang datang. Namun di sisi lain juga memberikan dampak negatif, dimana dampak negatif tersebut adalah kemacetan. Hal ini disebabkan lokasi dari PKL yang berada di sisi-sisi jalan mengakibatkan jalan yang biasanya dapat dilalui baik oleh kendaraan roda empat maupun roda dua menjadi hanya dapat dilalui oleh kendaraan roda dua. Namun berkaitan dengan hal tersebut belum ada perencanaan terkait PKL yang ada di Kawasan Sentra Primer Barat baik pada dokumen RTRW 2012 maupun RDTR 2014.

\section{KESIMPULAN DAN SARAN}

\section{Kesimpulan}

1) Perencanaan Kawasan Puri Indah sebagai Kawasan Sentra Primer Barat pertama kali dapat dilihat pada Perda DKI Jakarta No. 6 Tahun 1999, lalu dokumen perencanaan Urban Design Guidelines (UDGL) Tahun 2006, Perda DKI Jakarta No. 1 Tahun 2012, dan yang terakhir terdapat pada Perda DKI Jakarta No. 1 Tahun 2014. Dimana aspek-aspek yang direncanakan dari perencanaan yang paling awal sampai dengan yang paling terakhir saling berhubungan dan berkelanjutan. Pemerintah mulai memperhatikan perencanaan terhadap lingkungan yang ada di Kawasan Sentra Primer Barat, hal ini dapat dilihat pada Perda DKI Jakarta No. 1 tahun 2012, dimana perencanaan yang ada secara detail menjabarkan perencanaan terhadap lingkungan yaitu pembangunan taman kota, penanaman pohon pelindung, dan pembangunan serta peningkatan kapasitas saluran untuk mengatasi genangan air. Yang dimana pada peraturan-peraturan sebelumnya tidak terdapat perencanaan yang berkaitan dengan lingkungan. Secara keseluruhan berdasarkan peraturan daerah dan dokumen perencanaan tersebut, Kawasan Sentra Primer Barat direncanakan sebagai kawasan pusat perdagangan, jasa, dan campuran berintensitas tinggi untuk skala pelayanan nasional dan internasional serta sebagai pusat pemerintahan kotamadya Jakarta Barat.

2) Pada kondisi eksisting tahun 2019, kedudukan Kawasan Sentra Primer Barat yang direncanakan sebagai pusat kegiatan primer di Kota Jakarta Barat justru memiliki daya tarik dan arus pengunjung yang lebih rendah dibandingkan dengan Kawasan Grogol yang hanya merupakan pusat kegiatan sekunder. Hal ini disebabkan karena beberapa hal, yang pertama karena dulunya Kantor Walikota Jakarta Barat yang sekarang berada di Kawasan Sentra Primer Barat berada pada Kawasan Grogol. Lalu yang kedua Kawasan Grogol memiliki lebih banyak pusat kegiatan, dan yang ketiga Kawasan Grogol lebih mudah diakses menggunakan transportasi umum dibandingkan dengan Kawasan Sentra Primer Barat.

3) Jika dilihat berdasarkan beberapa aspek seperti jumlah penduduk, perkembangan kawasan, infrastruktur jalan, dan jaringan transportasi umum, kondisi eksisting Kawasan Sentra Primer Barat belum memenuhi sebagai pusat kegiatan primer di Kota Jakarta Barat. Hal ini dikarenakan masih terdapat banyak lahan kosong di Kawasan Sentra Primer Barat yang belum selesai dikembangkan serta infrastruktur jalan dan jaringan transportasi umum yang ada belum memadai dan menunjang Kawasan Sentra Primer Barat sebagai pusat kegiatan primer di Kota Jakarta Barat. 


\section{Saran}

1) Pemerintah harus lebih fokus di dalam pengembangan Kawasan Sentra Primer Barat terutama berkaitan dengan pengembangan kawasan, infrastruktur jalan, dan transportasi umum sehingga dapat menunjang Kawasan Sentra Primer Barat sebagai pusat kegiatan primer di Kota Jakarta Barat.

2) Implementasi dari perencanaan penyediaan ruang terbuka publik seperti RTH perlu ditingkatkan karena RTH berfungsi sebagai open space yaitu tempat berkumpul dan berinteraksi antar warga yang berada di Kawasan Sentra Primer Barat. Selain itu RTH juga dapat berfungsi sebagai area resapan air hujan.

3) Pemerintah perlu membuat perencanaan terkait PKL yang ada di Kawasan Sentra Primer Barat sehingga PKL yang ada menjadi lebih tertata dan menjadi salah satu daya tarik di Kawasan Sentra Primer Barat.

4) Dokumen perencanaan UDGL terkait Kawasan Sentra Primer Barat perlu dibuat secara detail dan jelas, sehingga pembaca dapat lebih mengerti dan memahami maksud dari perencanaan yang dibuat oleh pemerintah, sebagai contoh adalah UDGL terkait Kawasan Mega Kuningan, dimana perencanaan yang ada dijabarkan secara lebih detail dan jelas.

\section{REFERENSI}

Adisasmita, R. (2006). Pembangunan Pedesaan dan Perkotaan. Yogyakarta: Graha Ilmu Attoe, W. (1989). American Urban Architecture. Amerika Serikat: University of California Barnett, J. (2009). Urban Design. Amerika Serikat: University of Minnesota

Day, H. (2016). Comparative Planning Controls Report. Melbourne: Department of Environment, Land, Water, and Planning

Du Toit, J.L. (2010). A Typology of Designs for Social Research in The Built Environment. Disertasi, University of Stellenbosch

Murphy, R.E., Vance Jr., J.E. (1954). Delimiting the CBD. Econ. Geogr. 30(3), 189-222

Nazir, M. (2005). Metode Penelitian. Jakarta: Ghalia Indonesia

Peraturan Menteri Pekerjaan Umum (2014)

Shirvani, H. (1985). The Urban Design Process. California: University of California

Toit, J.D. (2015). The Routledge Handbook of Planning Research Methods. New York: Routledge Yaguang, S. (2011). Development and Characteristics of Central Business District Under the Philoshophy of Health. China:Dalian University of Technology, School of Architecture \& Fine Art 
